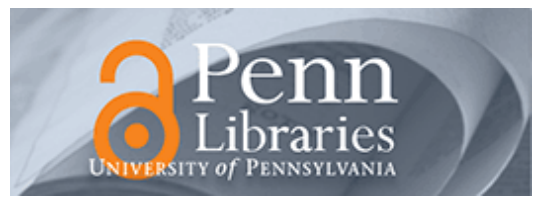

University of Pennsylvania

ScholarlyCommons

Management Papers

Wharton Faculty Research

$2-2010$

Institutions and the Internationalization of US Venture Capital

Firms

Işın Güler

Mauro F. Guillén

University of Pennsylvania

Follow this and additional works at: https://repository.upenn.edu/mgmt_papers

Part of the Business Administration, Management, and Operations Commons, and the International Business Commons

Recommended Citation

Güler, I., \& Guillén, M. F. (2010). Institutions and the Internationalization of US Venture Capital Firms. Journal of International Business Studies, 41 (2), 185-205. http://dx.doi.org/10.1057/jibs.2009.35

This paper is posted at ScholarlyCommons. https://repository.upenn.edu/mgmt_papers/84

For more information, please contact repository@pobox.upenn.edu. 


\title{
Institutions and the Internationalization of US Venture Capital Firms
}

\begin{abstract}
In recent years, venture capital firms have increasingly turned to foreign countries in search of investment opportunities. The cross-border expansion of venture capital firms presents an interesting case of internationalization, because they are at variance with both conventional portfolio and direct investment models. Given the specific nature of venture capital investing, a new theoretical perspective is needed to understand foreign venture capital investments. This paper contributes to international business research by examining the features of the institutional environment that influence venture capital firms' foreign market entry decisions, and how their effect changes as firms acquire experience. We report results on 216 American venture capital firms potentially investing in 95 countries during the 1990-2002 period. We find that venture capital firms invest in host countries characterized by technological, legal, financial, and political institutions that create innovative opportunities, protect investors' rights, facilitate exit, and guarantee regulatory stability, respectively. We also find that as firms gain more international experience, they are more likely to overcome constraints related to these institutions.
\end{abstract}

\section{Keywords}

institutional context, venture capital, longitudinal (or time-series) research design

Disciplines

Business Administration, Management, and Operations | International Business 


\title{
INSTITUTIONS AND INTERNATIONALIZATION \\ OF U.S. VENTURE CAPITAL FIRMS
}

\author{
Isin Guler \\ Kenan-Flagler Business School, University of North Carolina \\ CB3490 \\ McColl Building \\ Chapel Hill, NC 27516 \\ (919) 962-0691 \\ guler@unc.edu \\ Mauro F. Guillén \\ The Wharton School of the University of Pennsylvania \\ 2016 Steinberg Hall-Dietrich Hall \\ Philadelphia, PA 19104 \\ (215) 573-6267 \\ guillen@wharton.upenn.edu
}

\section{Running Title: INTERNATIONALIZATION OF U.S. VENTURE CAPITAL}

Keywords: Venture Capital, Institutional Context, Longitudinal

\section{Revise \& Resubmit at Journal of International Business Studies}

The authors thank the Mack Center for Technological Innovation for generous funding. 


\section{INSTITUTIONS AND INTERNATIONALIZATION OF U.S. VENTURE CAPITAL FIRMS}

We examine the institutions that facilitate the activities of U.S. venture capital firms in foreign markets. We report results using information on 1,010 American venture capital firms potentially investing in 95 countries during the 1990-2002 period. We find that venture capital firms prefer to invest in host countries characterized by technological, legal, financial, and political institutions that create innovative opportunities, protect investors' rights, facilitate exit, and guarantee regulatory stability, respectively. 


\section{Introduction}

The theory of foreign direct investment seeks to explain various aspects associated with the control exercised by a firm over the production of a good or service in at least one location other than its home country. As originally proposed by Hymer (1976) in the late 1950s, the difference between direct and portfolio investment lies precisely in the intention of the firm to exercise managerial control over the foreign operation. In recent years, venture capital firms have increasingly turned to foreign countries in search of investment opportunities. The cross-border expansion of venture capital firms presents an interesting case of internationalization because their foreign investments cannot be classified in a straightforward manner. In some respects, venture capital foreign investments appear to share some features of those characterized in the literature as portfolio investments. First, the venture capital firm is a financial intermediary operating between the ultimate investor and the entrepreneur. Second, the venture capital firm's ultimate goal is not to produce a good or a service for profit, but to obtain a capital gain with which to reward the ultimate investor. Third, although the venture capital firm may dispatch one or more directors to the board, the managerial hierarchy of the foreign venture does not functionally report to the venture capital firm. Moreover, venture capital firms typically invest as part of a syndicate, and rarely are majority investors.

Venture capital firms, however, behave as much more than pure financial intermediaries, given that they also provide the venture with organizational, managerial, industry, and even technological expertise. Moreover, they exert much more frequent and extensive control over the invested company than the typical portfolio investor (Gompers \& Lerner, 2000). Venture capital firms make capital investments in "opportunities" that typically entail high risk, and a potential of high returns. These opportunities are not single resources or means of production, but individual companies that constitute a unique "bundle of resources" (Penrose, 1959). Given the specific nature of venture capital investing, one that is at variance with both conventional portfolio and direct investment models, a new theoretical perspective is needed.

In this paper we explore the distinctive aspects of foreign venture capital investing by examining the reasons why venture capital firms decide to invest in some foreign locations but not in others. We adopt an 
institutional perspective focused on the characteristics of countries that affect the decision by a venture capital firm to invest in foreign companies. The conventional wisdom is that venture capital is an activity difficult or nearly impossible to organize effectively and successfully across borders. Participants in the industry emphasize the local nature of deal-making (Freeman, 2005). Research has documented that venture capitalists tend to fund ventures located relatively close to their domicile so as to facilitate monitoring and control (Sorenson \& Stuart, 2001). Therefore, it becomes relevant to study what institutions might help these organizations overcome the difficulties of doing business in foreign environments.

Though still small, cross-border venture capital activity has risen quickly since the early 1990s. "VCs who once bragged about never driving more than half an hour to visit a portfolio company are jetting to Australia for optical engineers, Israel for security whizzes, India and Kazakhstan for brute software coding, South Korea for online gaming, and Japan for graphics chips. For growth across the board, China is the place to go." According to one venture capitalist, "VCs in Silicon Valley used to pride themselves on being local... That was well and good when the U.S. was the mecca for technology." "2 In many countries around the world, local practices and regulations are being overhauled so as to make it easier for foreign venture capital firms to operate. For instance, a Chinese legislator and economic expert argued in an interview that "venture capital is not conflicted with Socialism." ${ }^{3}$ Understanding the cross-border activities of venture capital firms is of increasing relevance as the world economy shifts toward knowledge-intensive activities. The venture capital industry has played an important role in spurring innovation and entrepreneurship in the United States. In recent years, U.S. venture capital firms started to look abroad for investment opportunities in other countries. This trend is important not only in providing new opportunities for venture capital firms, but also in contributing to the development of local economies through entrepreneurship and innovation.

By examining the foreign location choices of venture capital firms, we strive to contribute to the international business literature by offering a systematic examination of the importance of host-country institutions on foreign market choice of venture capital firms through a large-sample study. We argue that the decision of venture capital firms to invest in companies located in foreign markets is driven by 
institutions that foster the availability of innovative and entrepreneurial opportunities, the ability to commercialize these opportunities, and the extent to which the institutional infrastructure of each country enables the appropriation of returns.

\section{The Venture Capital Industry in the U.S. and around the World}

The venture capital firm is a genuinely American institution. In 1946 a group of Boston academics and financiers created American Research and Development. A key innovation came about in 1958, when one firm organized itself as a limited partnership, in which limited partners or investors provided funds to general partners or venture capitalists to invest in entrepreneurial ventures. This organizational form enabled the venture capitalist to be exempt from the prohibitions to own more than 10 percent of the equity and to serve on the board of directors of portfolio companies. The limited partnership became the dominant form of incorporation in the U.S. Nowadays, the typical venture capital firm has anywhere between two and over thirty general partners. The amount of capital under management can range from 10 million to several billion dollars (Fenn, Liang, \& Prowse, 1997).

Venture capital firms ${ }^{4}$ act as intermediaries between investors in search of investment opportunities and entrepreneurs in need of capital. They raise money from investors of various kinds, placing it into a fund which they use to acquire equity stakes in entrepreneurial ventures. At the end of a predetermined periodtypically 7-10 years - the investments are liquidated and the proceeds returned to the investors, except for a management fee. Venture capitalists provide entrepreneurs and their companies with funding, strategic advice, industry knowledge, contacts, and reputation (Gompers \& Lerner, 2001, Gompers \& Lerner, 2000).

The venture capital industry has been one of the major driving forces behind innovative activity and growth of high-technology industries in the U.S. economy. Between 1998 and 2005, almost half of the venture capital investments were technology-related (Global Private Equity, 2006). Although venture capital outlays represented only 3 percent of total corporate investment between 1983 and 1992, they resulted in 8 percent of all U.S. industrial innovations (Kortum \& Lerner, 2000). As a result, venture capital has been a significant driver of the U.S. economy through spurring entrepreneurial activity. 
Venture capital invested during the period 1970-2005 created 10 million jobs and over \$2.1 trillion in revenue. In 2005, venture capital-backed companies represented 9 percent of total U.S. private sector employment and 16.6 percent of GDP (Venture Impact, 2007).

The success of the U.S. venture capital industry in financing innovation and contributing to growth has encouraged venture capital activity in other countries. Although private equity and venture capital investment around the world are comparatively smaller, many countries report large growth rates. For instance, during 2005 private equity investments grew by 45 percent in India, and 328 percent in China (Global Private Equity, 2006). The early experiments with venture capital in countries like Germany and Japan failed in spite of government or corporate backing (Becker \& Hellmann, 2005, Kenney, Han, \& Tanaka, 2002). Later developments gave rise to venture capital activity that differed in structure and operation from their U.S. counterparts, always in response to unique institutional demands (Bottazzi, Da Rin, \& Hellmann, 2004). Some of the factors that have been argued to affect the growth of venture capital activity include appropriate structures to protect investor returns (Becker \& Hellmann, 2005), the level of economic development, the availability of exit options (Kenney, Han, \& Tanaka, 2002) as well as the quality of the national system of innovation and levels of entrepreneurship (Becker \& Hellmann, 2005). A small number of studies has examined the growth of the domestic venture capital industry in a number of countries, and linked it to the institutional environment of the country. A comparative study of German and U.S. venture capital markets suggests that the existence and strength of the stock market is a key determinant of venture capital financing (Black \& Gilson, 1998). A crosscountry study of venture capital investing in 21 countries finds support for the importance of IPOs and government policies (Jeng \& Wells, 2000). ${ }^{5}$ A recent study of domestic investment decisions in three countries shows that venture capitalists in rule-based economies base their decisions more on market characteristics, while those in relationship-based economies rely more on characteristics of the human capital (Zacharakis, McMullen, \& Shepherd, 2007). However, very little research has examined the 
internationalization decisions of venture capital firms, and the patterns of cross-border investment (see Wright, Pruthi, \& Lockett, 2005, Zalan, 2004 for reviews.)

\section{Institutions and Foreign Market Entry by Venture Capital Firms}

Venture capital firms depend on a number of institutions in order to operate, including technological institutions providing for entrepreneurial opportunities, legal institutions facilitating contracts between the firm and the entrepreneur, financial institutions making it possible to exit the investment, and political institutions preventing any harm to or curtailment of their property rights. Our main argument is that venture capital firms invest in companies located in countries or markets with attractive technological, legal, financial, and political institutions.

In examining the effect of host-country institutions on venture capital investment, we define institutions as "multifaceted, durable social structures, made up of symbolic elements, social activities, and material resources" which "provide guidelines and resources for acting as well as prohibitions and constraints on action" (Scott, 2001: 49-50). Several areas of recent institutional theory and research are relevant to the analysis of the host-country institutions venture capital firms find attractive. First, institutions that support innovation and technology are important to venture capital firms because venture capital firms tend to focus their attention on high-tech industries. The literature on national systems of innovation offers an institutional framework for the comparative analysis of the characteristics, organization and performance of countries in the area of technology. This line of research draws on institutional analysis in economics, political science, sociology and/or organizational studies (Furman, Porter, \& Stern, 2002, Nelson \&

Rosenberg, 1993, Patel \& Pavitt, 1994, Porter, 1990, Whitley, 1992). Second, the rapidly growing literature on cross-national patterns of corporate governance and finance provides a framework for understanding the complex relationship between legal systems, financial markets, and capitalist development in general, and the legal protection of investors' rights in particular (Guillén, 2000, La Porta, Lopez-de-Silanes, Shleifer, \& Vishny, 1998), another issue that is of central concern to venture capital firms. Third, the literature on political hazards uses institutional economics and positive political theory to study the conditions that make 
for a stable political environment (Henisz, 2000a, Henisz, 2000, Henisz \& Williamson, 1999). This aspect is of cardinal importance to venture capital firms given that they need to ensure that the investment returns will not be expropriated. Based on these theoretical perspectives, let us turn to examining how technological, legal, financial, and political institutions affect foreign location choice by venture capital firms.

\section{Institutions Supporting Knowledge and Technology: National Systems of Innovation}

The literature on national systems of innovation has conceptualized and documented that countries, and regions within countries, differ in terms of the inputs allocated to the creation of knowledge, technology and innovation, the quality of the institutions that help transform those inputs, and the resulting level of performance (Almeida \& Kogut, 1999, Furman, Porter, \& Stern, 2002, Kogut \& Zander, 1993, Nelson \& Rosenberg, 1993, Patel \& Pavitt, 1994, Porter, 1990, Romer, 1990). Although science and technology have become more global in nature over the last two decades, the country continues to be a relevant unit of analysis. Globalization has not erased differences in effort or outcomes across countries, resulting in persistent knowledge and technological gaps, for two reasons. First, many of the institutional actors involved in the effort (i.e. governments, universities, trade associations) are distinctively national or subnational in character (Nelson \& Rosenberg, 1993). And second, knowledge and technology move more easily within than across national borders, as a large body of empirical research has established (Guillén, 1994, Kogut \& Chang, 1991, Patel \& Pavitt, 1994).

Differences in national levels of innovation are likely to influence the level of entrepreneurial activity, and as a result, the attractiveness of the country to foreign venture capital investors. Entrepreneurs and firms tend to agglomerate in locations with high levels of institutional support for innovation. For instance, prior work documents that new ventures benefit from access to resources such as human capital and from knowledge spillovers by locating close to universities and other firms (Audretsch, Lehman, \& Warning, 2005, Hall, Link, \& Scott, 2003, Stuart \& Sorenson, 2003a). In particular, geographic proximity facilitates spillovers, as inventors in universities and firms become more aware of each other's work, and 
develop new knowledge through more frequent face-to-face interaction (Adams \& Jaffe, 1996, Jaffe, Tratjenberg, \& Henderson, 1993). While large, technologically advanced firms benefit from such externalities, small, less technologically advanced firms stand to benefit the most from spillovers from local sources of knowledge (Alcacer \& Chung, 2007). As a result, we expect venture capital firms as well as entrepreneurs concentrating in locations characterized by high innovative activity (Powell, Koput, Bowie, \& Smith-Doerr, 2002). While prior work has examined the regional agglomeration of entrepreneurs and venture capital firms (Florida \& Kenney, 1988, Kenney, Han, \& Tanaka, 2002, Stuart \& Sorenson, 2003a), the impact of national systems of innovation on venture capital foreign investment has not been addressed in the literature.

We argue that national systems of innovation influence the extent of profit-making opportunities and entrepreneurial activity in each market. New ventures choose among markets based on the existence of institutions that support innovation and technological development (e.g. Audretsch, Lehman, \& Warning, 2005, Hall, Link, \& Scott, 2003, Stuart \& Sorenson, 2003a). In turn, venture capital firms scan the environment for attractive opportunities, i.e. new innovative ideas in which to invest, and often find them in areas that have to do with the application of new knowledge or technology (Gompers \& Lerner, 2001, Gompers \& Lerner, 2000). Countries with vibrant institutions that support research and innovation are likely to become more attractive for venture capital firms looking to expand internationally. Hence, we predict:

Hypothesis 1: The attractiveness of a new market for venture capital firms increases with the local level of knowledge and technology.

\section{$\underline{\text { Institutions Supporting Venture Capital Transactions }}$}

Venture capital involves a considerable "leap of faith," given the nature of young entrepreneurial ventures and the uncertainties about their success (Gompers \& Lerner, 2001:87). Hence, the venture capital firm needs to use certain monitoring and enforcement mechanisms to ensure that those running the invested company do so in a way consistent with the interests of the investors, who tend to have a preference for an 
exit within a number of years through an initial public offering (IPO). This chain of events is only possible in the presence of appropriate legal, financial and political institutions. The most important legal institution is corporate law, which specifies the rights and obligations of owners and managers. The existence of large and active equity markets is required in order to materialize the venture capitalist's preferred exit option, namely, the IPO. Finally, political institutions need to provide a dose of stability and predictability so as to placate investors' fears about future changes in rules and regulations. Let us analyze each of these in turn.

Legal Institutions: Corporate Law. Laws fulfill two roles that facilitate economic action. First, they define legal persons that transcend individuals, create negotiable instruments, and establish how negotiations and interactions can take place (Trevino, 1996). Second, the legal order defines and protects the legitimate interests of the various parties. Weber (1978:328-329) observed that although "in most business transactions it never occurs to anyone even to think of taking legal action, $[\ldots]$ economic exchange is quite overwhelmingly guaranteed by the threat of legal coercion.” Firms and investors prefer to operate in a context in which legal institutions enable and protect them (Trevino, 1996).

Legal institutions are relevant to the growth of venture capital. Recent research on the contractual relationship between the entrepreneur and the venture capitalist highlights that the latter seeks to diversify its holdings by investing small amounts in each venture, and to delegate control to the entrepreneur during the normal course of operations, but to reassert its rights as owner if things take a turn for the worse (Lerner \&

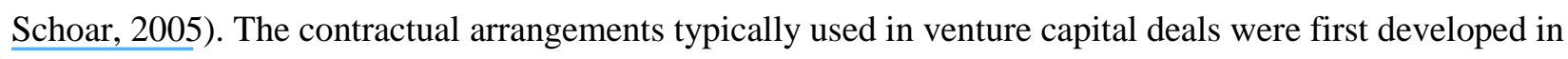
the United States (Gompers \& Lerner, 2001, Gompers \& Lerner, 2000, Sahlman, 1990). The United States, however, provides a legal environment for venture capital activity that is not present in every country around the world. Thus, the transfer of the contractual arrangements to other countries may prove problematic (Bottazzi, Da Rin, \& Hellmann, 2005, Kaplan, Martel, \& Stromberg, 2005, Lerner \& Schoar, 2005).

Comparative legal scholarship (Glendon, Gordon, \& Osakwe, 1994, Reynolds \& Flores, 1989) and more recent economic analyses (La Porta, Lopez-de-Silanes, \& Shleifer, 1999, La Porta, Lopez-de-Silanes, Shleifer, \& Vishny, 1998) have documented that owners' interests receive different degrees of legal 
definition and protection depending on the legal system. This line of research argues that owners' or investors' rights are defined and protected in varying ways and to different degrees depending on the legal tradition that provides the foundation for corporate law: (1) English common law, (2) French, (3) German, (4) Scandinavian, and (5) formerly socialist law. The English common law tradition is shaped by the decisions of judges ruling on specific issues, or, as Weber (1978:890) put it, "English legal thought is essentially an empirical art." By contrast, the French and German traditions emerged from Roman civil law, which "uses statuses and comprehensive codes as a primary means of ordering legal material" (La Porta, Lopez-de-Silanes, Shleifer, \& Vishny, 1998:1118). The French Commercial Code was issued by Napoleon in 1807, while the German Commercial Code was adopted in 1897 under Bismarck's influence.

Scandinavian legal systems are in part based on civil law.

English, French, and German corporate law diffused widely throughout the world following patterns of imperial, military, economic, or cultural influence, which has resulted in varying degrees of protection of owners' rights. Thus the former British colonies - including the U.S., Canada, Australia, Ireland, Singapore, and many others in Africa and South Asia-adopted English common law. French law spread not only to the francophone colonies in the Middle East, Africa, Indochina, Oceania, and the Caribbean but also to the Netherlands, Portugal, Spain, Italy, and their respective colonies. The German legal tradition shaped corporate laws in Austria, Switzerland, Greece, Hungary, the Balkans, Japan, Korea, Taiwan, and China, among other countries. Lastly, the former socialist countries constitute a separate category because their legal systems, though in many cases influenced by either French or German law, have been in flux since 1989 and have largely failed to provide a sound basis for effective corporate governance (Schneper \& Guillen, 2004, Spicer, McDermott, \& Kogut, 2000).

A comparative analysis of corporate legal traditions reveals that the best protection of owners' rights is awarded by English common law, followed by Scandinavian and German law, while the French legal tradition provides the worst protection. Research has also demonstrated that enforcement of owner 
protections and dispute-resolution time differs greatly across countries, and that these variables are highly correlated with the level of legal protection itself (Djankov, La Porta, Lopez-de-Silanes, \& Shleifer, 2003).

Based on this evidence and analysis, we argue that venture capitalists prefer to operate in countries with a legal system that protects the rights of the investor. In the case of venture capital firms, the reasons for this preference are two-fold. First, they tend to respond to legal regimes offering poor investor protection by increasing the size of their equity stakes, a practice that constrains the ability of the venture capital firm to diversify its portfolio (Bottazzi, Da Rin, \& Hellmann, 2005, Lerner \& Schoar, 2005). Second, entrepreneurs' appetite for venture capital funding may also decline because of the additional equity stake demanded by the venture capitalist. Therefore, we formulate:

Hypothesis 2: The attractiveness of a new market for venture capital firms will be greater if the local legal system is based on English common law.

Financial Institutions: Equity Markets. Financial markets are part of the institutional infrastructure enabling organizational founding and growth (e.g. Stuart \& Sorenson, 2003b). The stock market is certainly important for venture capital firms. Venture capitalists do not indefinitely hold on to the equity in the entrepreneurial venture but rather seek to realize capital gains (and distribute them, net of management fees, to the limited partners), typically through IPOs, which historically represent the majority of venture returns (Freeman, 2005, Gompers \& Lerner, 2000). Hence, the size and dynamism of the equity market in the country in which the venture is located promises better prospects for a successful exit, thus increasing the attractiveness of investments (Black \& Gilson, 1998, Leachman, Kumar, \& Orleck, 2002). ${ }^{6}$ As venture capitalists exit investments successfully, they can help investors recycle capital towards new opportunities and attract new funds (Black \& Gilson, 1998).

Countries differ massively in terms of equity market development. For instance, total stock market capitalization as a percentage of GDP ranges from as low as 15 in Poland, 26 in India, 27 in Brazil, 35 in Germany, 37 in China, 44 in Israel or 46 in South Korea, to 68 in France, 106 in the United States and 119 in 
the United Kingdom, to name but a few examples. Given the importance of the development of the local stock market for the attraction of capital to venture capital firms and for the realization of capital gains, we formulate:

Hypothesis 3: The attractiveness of a new market for venture capital firms increases with the development of the local stock exchange.

Political Institutions: Policy Stability. Political institutions are a key determinant of the attractiveness of a location from the vantage point of an outsider. Firms benefit from the regular and predictable implementation of public policy (Guthrie, 1997, Trevino, 1996). The venture capital firm—like other types of firms - would generally prefer to invest in countries with low political hazards. The reason is that the existence of investment opportunities related to knowledge and technology, the presence of appropriate legal institutions protecting investors' rights, and the availability of financial channels to realize capital gains do not preclude the possibility that policymakers might be tempted to change laws, rules or regulations concerning those three aspects in order to appropriate investors' gains in full or in part. As institutional theorists argue, laws, rules and regulations are seldom completely objective and unambiguous (Scott, 2001:169-170). The extent to which laws, rules and regulations can potentially be changed or reinterpreted creates uncertainty for the regulated.

Henisz (2000a, 2000) proposes to conceptualize political hazards as a structural attribute of countries that may change over time. Countries differ in terms of the number of "political constraints." As that number grows, so does "a government's ability to credibly commit not to interfere with private property rights," an argument first advanced as relevant to the study of capital investment by North and Thomas (1973) (see also North, 1990). The constraints increase with the number of independent branches of government with veto power (executive, higher legislature, lower legislature, judiciary, local administration), and the degree to which veto points are controlled by different parties (i.e. when the various branches of government are not aligned). Firms, including venture capital firms, should anticipate little 
change in relevant regulations or property rights protections, or in their interpretation, to the extent that policymaking is subject to institutional constraints, thus providing for a more stable political environment for investment. The empirical evidence confirms that firms prefer to do business in countries with low political hazards (Henisz \& Delios, 2001). Thus, we formulate:

Hypothesis 4: The attractiveness of a new market for venture capital firms increases with the local level of policy stability.

\section{Research Setting, Data, and Methods}

We test the effects of institutions on the internationalization of venture capital firms with systematic data on their foreign investment activities between 1990 and 2002. The U.S. venture capital industry grew significantly during this period, in terms of both capital available for investment and the number and amount of actual investments. Activity in the U.S. and abroad peaked in the year 2000, which lies within our period of observation. We compiled the venture capital investment data from the VentureXpert database provided by Venture Economics, ${ }^{7}$ which collects information through an annual survey of over one thousand private equity partnerships in the U.S. This database has been used extensively in venture capital research (Barry, Muscarella, Peavy III, \& Vetsuypens, 1990, Gompers \& Lerner, 2000, Megginson \& Weiss, 1991, Sahlman, 1990, Shane \& Stuart, 2001). Although it tends to oversample investments in California companies, most of the concerns about VentureXpert's quality have to do with issues surrounding capital disbursed and valuations (Kaplan, Martel, \& Stromberg, 2005), which are not the focus of this paper.

Given that our analysis focuses on the foreign investments of venture capital firms, we observed the entire population of 1,010 U.S.-domiciled firms between 1990 and 2002. Each of these firms had a presence in the venture capital industry, although some of them also engage in other forms of later-stage private equity. ${ }^{8}$ In order to capture causal relationships between the dependent variable and the independent variables, we used a one-year lag. We therefore empirically examined investments over the twelve-year period between 1991 and 2002. As of the end of 2002, 216 of the 1,010 venture capital firms made 1,714 
rounds of investment in 920 ventures located in 40 different foreign countries. The largest investors were Warburg Pincus, Advent International Corporation, and Japan/America Ventures. The distribution of rounds by investment stage was as follows: startup or seed (6 percent), early stage (22), expansion (51), later stage (7), buyout or acquisition (7), and other (6). We included all of these rounds in our primary analysis and then checked if excluding the latter three categories affected the results. We excluded from all analyses 17 investments in companies that had gone public before the U.S. venture capital firm invested.

Dependent Variable and Unit of Analysis. The dependent variable is a non-negative integer count of venture capital investments in each country during a given year. Our empirical analysis focuses on investment counts and not on the size of the investment because one can only observe the latter if an investment actually takes place. Focusing on the amount invested would unavoidably introduce a selection bias into the analysis of the impact of institutions.

We used two different ways of constructing the dependent variable to bolster the robustness of our findings. First, we took into consideration the first round of investment in each venture undertaken by each venture capital firm $\mathrm{i}$ in each country $\mathrm{j}$ and year $\mathrm{t}$, yielding 687 nonzero combinations because some firms invested in more than one venture in the same country-year. Second, we considered each investment round as a separate investment by each venture capital firm in a given country-year, yielding 896 nonzero combinations. (Again, some of the 1,714 rounds of investment took place in the same country-year).

The 1,010 venture capital firms in the population were active for an average of seven years between 1991 and 2002. We obtained reasonably complete background information on 95 countries (see Appendix for a list), although for some of them the independent variables were not available for each and every year. The final sample for analysis consists of 502,208 firm-country-year combinations. ${ }^{9}$

Independent Variables. We follow the existing literature in measuring host-country institutions supporting innovation and technology (hereafter referred to as technological institutions) with outcome measures of the level of innovative activity in each country (Furman, Porter, \& Stern, 2002, Guler, Guillén, \& MacPherson, 2002, Kumaresan \& Miyazaki, 1999, Noisi, 2002). We use two separate indicators to 
measure the level of innovative activity in country j: the number of U.S. patents granted to establishments in country $\mathrm{j}$ during year $\mathrm{t}-1$, and the number of scientific and technical articles authored by residents of country $\mathrm{j}$ during year t-1. Patents and articles are widely used empirical indicators of the performance of national systems of innovation (Furman, Porter, \& Stern, 2002, Guler, Guillén, \& MacPherson, 2002, Kumaresan \& Miyazaki, 1999, Noisi, 2002), although they do not capture the full extent of innovative activity (Nelson \& Rosenberg, 1993). They are especially well-suited to a study of the factors that attract U.S. venture capital firms to foreign environments because they are the result of both the level of inputs and the productivity of the system. It is also important to note that the U.S. Patent and Trademark Office and the Institute of Scientific Information are sources of information on knowledge, technology and innovation routinely used by U.S. venture capital firms. Our field interviews revealed that venture capitalists and industry experts use patents and scientific articles as indicators of innovative activity in foreign countries, or to legitimate their decisions. Either way, countries with greater counts of patents and articles will be more attractive to the venture capital firm. We obtained the patent data from the NBER database (Hall, Jaffe, \& Trajtenberg, 2001), and the publication data directly from the Institute of Scientific Information's Science Citation Index (which includes journals in several languages). We preferred to measure the level of knowledge in each country with a count of patents filed in the U.S. rather than those filed locally, since differences in patent laws limit the comparability of such figures in different countries (see Maskus, 2000). Using both measures allows us to test the robustness of our results to unobserved sources of heterogeneity that might influence patenting or publication. We normalized both measures by the GDP of each country j during year t- 1 .

We used various sources to calculate the indicators of supporting institutions. In order to capture the effect of legal institutions, we used La Porta et al.'s (1998) classification of countries according to legal tradition, omitting common-law countries for ease of interpretation. In results not reported, we also added a dummy variable indicating if English is the official or the most widely-spoken language. Since the results were similar, we just included the set of legal dummies. We measured local stock market development with total market capitalization as a percentage of GDP (World Bank, 2004). We also considered stock market 
turnover ratio and changes in the number of listed companies as further indicators of the availability of exit options. Capitalization has the additional advantage that it is correlated with the two ways in which venture capitalists obtain their returns, namely, helping ventures go public and finding an acquirer. While a larger capital market facilitates IPOs, it also increases availability of funds that enables acquisition activity.

Finally, we measured political institutions with the political constraints index, which captures the limitations on policymakers to unilaterally change the existing policy regime (Henisz, 2000). This indicator ranges between 0 (most hazardous) and 1 (most constrained, i.e. stable). The political constraint index is historically highly correlated with the risk indexes included in the International Country Risk Guide (ICRG, 1996) (Marshall \& Jaggers, 2000).

Firm-Level Control Variables. We included in all models three firm-level controls: the number of ventures funded by the venture capital firm in the United States as of year t-1 in order to account for unobserved firm heterogeneity in skills or capabilities, what researchers have called venture capital firm “sophistication,” as well as size (Bottazzi, Da Rin, \& Hellmann, 2005, Gompers \& Lerner, 2000:236, Kaplan, Martel, \& Stromberg, 2005); the number of ventures funded by the venture capital firm in foreign countries as of year t-1, which controls both for unobserved firm heterogeneity in general, and for the propensity to invest abroad in particular.

Country-Level and Time Control Variables. We included a control for the size of the economy, measured as GDP in constant 1995 U.S. dollars (World Bank, 2004), and for other sources of unobserved cross-national heterogeneity in the first stage of our estimation procedure (see below). We also included either a year trend, a full set of year dummies, or both a linear and a quadratic term for year.

Estimation Method. The usual approach in estimating models with a non-negative count as the dependent variable is to assume that the error structure follows a Poisson distribution (Cameron \& Trivedi, 1998). However, our dependent variable exhibits overdispersion for two reasons. First, the data include a large number of zero counts since the dataset includes all possible venture capital firm-country-year combinations. Since overdispersion occurs in part as a result of excess zeros, we use a zero-inflated count 
model. Zero-inflated count models assume that the process generating the excess zeros is different from the process that generates the non-zeros (Greene, 1997, Tu, 2002). Second, since our data contain evidence of overdispersion due to unobserved heterogeneity as well as excess zeros, we estimated the number of investments with a zero-inflated negative binomial model, nested within a logit model estimating the likelihood of zero investments for the venture capital firm-country pair during year t. In estimating the probability of zero investments, we used three predictor variables as well as a year control. The first variable is the cumulative number of ventures that U.S. venture capital firms had funded in country $\mathrm{j}$ as of year $\mathrm{t}-1$. This measure accounts for unobserved cross-national differences in taxes and other incentives, for which available data only covers the OECD countries (Jeng \& Wells, 2000). The second variable is the cumulative number of foreign countries entered by venture capital firm i as of year $\mathrm{t}-1$, which serves as an additional control for firm heterogeneity concerning the pursuit of foreign opportunities and for a greater propensity to go abroad. The third variable is each firm's centrality score in the syndication network, which reflects the status ordering in the local network (Podolny, 2001, Podolny, 2005), and plays an important role in firms' propensity to invest abroad (Guler \& Guillen, 2008). We used Bonacich's (1987) eigenvector centrality measure to control for the firm's status. For each year t, we calculated the centrality score using the information for years t-3, t-2 and t-1. The centrality score ranges between zero (for isolated firms), and one (for firms that syndicate with other high-status actors). Fourth, we controlled for the level of policy stability in the country, given prior findings about how political uncertainty may influence patterns of market entry (Henisz and Delios, 2001). Last, we controlled for the number of the firm's syndicate partners which have already expanded into the focal country, since partners' experience in a country may reduce the uncertainty related with entering a new market (e.g. Henisz and Delios, 2001). Given that there are multiple observations for each venture capital firm, we used the Huber-White-Sandwich estimator of variance yielding robust standard errors.

Descriptive Statistics. Tables 1 and 2 display the sample descriptive statistics and the correlations, which are based on the sample of 502,208 venture capital firm-country-year observations. Most of the 
pairwise correlations are very low. The few exceptions involve the number of U.S. patents, which is highly correlated with some of the legal tradition dummies, stock market capitalization, policy stability, GDP, and the number of funded ventures in each country. The results reported below are robust to the removal of one, two or three of these variables, indicating that multicolinearity does not seem to be a problem.

\section{Results}

Table 3 displays the results using different model specifications. The overdispersion parameter is significant in all models (not shown), indicating that one cannot assume equal mean and variance. Hence, the negative binomial model is appropriate. Vuong tests comparing the estimates of the zero-inflated and non-nested negative binomial models confirmed that at least some of the unobserved heterogeneity is due to an excess zero count. Thus, correcting for zero-inflation is appropriate.

The results of the first-stage logit analyses predicting zero counts appear at the bottom of the table. Both the cumulative number of ventures in each country funded by U.S. venture capital firms as of year t-1, and the cumulative number of countries entered by each venture capital firm as of year t-1 are significant. The centrality measure also has a significant and negative coefficient. The negative signs mean that the three variables reduce the likelihood of zero counts, or conversely, increase the likelihood of entry into the country.

The results of the second-stage analyses predicting the numbers of ventures or rounds invested lend support to three of our four predictions. The first models include the control variables and the measures for technological institutions (columns 1-4). The second set of specifications adds the legal tradition dummies (columns 5-8). In these models, countries with legal traditions other than English common law attract less venture capital investment, although the result is not robust to the indicator of opportunities (patents or publications). Finally, columns 9-12 show the fully specified models. The results lend support to the predictions that the numbers of ventures and rounds invested by U.S. venture capital firms increase with 
local technology or knowledge (H1), the size of financial markets (H3) and policy stability (H4). The legal tradition variables suggest that countries with German and Scandinavian legal traditions are significantly less attractive than those with English legal tradition. However, French and socialist legal tradition dummies are not significant. We therefore find partial support for $\mathrm{H} 2$. The control variables behave as would be expected in most cases. The venture capital firm's international experience is significant, whereas its U.S. experience is not. The size of the economy also exerts a positive effect.

We undertook a battery of robustness checks which resulted in support for the same five hypothesized effects. First, we included dummy variables controlling for the three most assiduous investors (Warburg Pincus, Advent International Corporation, and Japan/America Ventures). It is important to note that we already control for each venture capital firm's U.S. and international experience. Second, we estimated each model excluding from the dependent variable the 20 percent of rounds coded by VentureXpert as "late stage," "buyout/acquisition" or "other." Third, we explored other indicators for the size and vibrancy of the local equity market. In particular, we calculated for the 95 countries in the sample the net change in the number of listed firms from year t-1 to year t. This variable tended not to be significant. Fourth, we controlled for each venture capital firm's international experience in early-stage venture capital deals, measured as the number of early-stage and start-up investments in foreign countries as of year t-1, to account for the fact that early financing is more difficult to undertake over a long distance, i.e. in a foreign country (Wasserman, 2003). This variable was not significant. Fifth, we controlled for the domestic lending interest rate, as a proxy for investment conditions in each country. This variable was negative and significant, perhaps because high interest rates discourage local entrepreneurship in the first place. Sixth, in order to test whether the effects of technological institutions, legal traditions or transnational communities were merely artifacts of the level of English language proficiency of the local population, we ran the regressions adding a control for countries in which English is the official or the most widely-spoken language. Seventh, in order to control for the incentive structure in the country, we included the Index of Economic Freedom in our analyses (Beach and Miles, 2006). This variable was not significant. Eighth, we 
controlled for OECD membership, in order to account for the possibility that the factors affecting investment in developed countries may be different from those in developing countries, and our measures merely capture the level of development. While OECD membership was significant in predicting venture capital investment, our results on predicted effects remained similar. Lastly, we used a panel negative binomial specification with venture capital firm fixed effects. Since the number of firms is large, the models would not easily converge. To avoid this problem, we drew a smaller sample of investments by randomly selecting $110 \mathrm{VC}$ firms of the total 1,010. The results did not change. We also tried using a negative binomial specification with country fixed effects. These models did not converge, likely due to the fact that several of our country-level variables (e.g. GDP) do not vary significantly over the sample duration, and capture any within-country variation. We are therefore confident that our controls (e.g. number of prior VC investments in each country and GDP) adequately capture the unobserved heterogeneity at the country level.

The estimates reported in Table 3 are not only robust to a variety of changes in the model's specification and to the inclusion of additional control variables, but also large in magnitude. Table 4 shows the effect on the number of ventures or rounds of a one standard deviation change in each of the significant independent variables. To gain some perspective, countries like Austria, Belgium, Canada, France, the Netherlands, Japan, Germany or the United Kingdom tend to score about one standard deviation higher on most of the hypothesized variables than countries such as Argentina, Brazil, Indonesia, Thailand, Malaysia, the Philippines, Poland or the Czech Republic. According to the parameter estimates reported in Table 5, a one standard deviation change in U.S. patents leads to a 97.7 percent increase in the number of ventures invested and a 103.1 percent increase in the number of rounds. The estimated percent increases for scientific publications were 46.3 percent for ventures and 86.7 percent for rounds. Depending on the model, the estimated changes for stock market capitalization range between 35 and 74 percent, and the changes for policy stability range between 28 and 55 percent.

\section{Discussion and Conclusion}


This paper has offered a systematic analysis of the role of institutions in determining the attractiveness of a foreign country to firms. It contributes to international business research by examining the features of the institutional environment that influence venture capital firms' foreign market entry decisions. Firms pick and choose the environments in which they wish to operate, largely in terms of the nature and quality of the institutions present in them. Thus, firms find it easier to operate in environments in which they have access to the required institutional architecture or infrastructure. Our paper adds to this literature a finer-grained theoretical development of this idea and robust empirical evidence in its favor.

Our results highlight the importance of national systems of innovation in attracting foreign venture capital investment. Our theoretical and empirical analysis is in line with recent work in international business research emphasizing that firms frequently expand abroad in order to enhance and complement their existing capabilities with new knowledge (Alcacer \& Chung, 2007, Chung \& Alcacer, 2002). While this body of work has focused on the expansion of firms operating in research-intensive industries through direct investment, especially in R\&D activities (e.g. Florida, 1997, Kuemmerle, 1999), the inclination of venture capital firms to do business in countries with a highly developed system of innovation and plentiful technology is fully consistent with prior findings. Even though venture capital firms may not have the objective to internalize the local sources of knowledge, they still stand to benefit from identifying local entrepreneurial ventures which create and exploit such knowledge.

Our paper contributes to the small but burgeoning literature on international venture capital investments. As opposed to most research in this area, which compares the precedents of domestic venture capital industries (Becker \& Hellmann, 2005, Black \& Gilson, 1998, Kenney, Han, \& Tanaka, 2002), we focused on the cross-border investments on U.S. venture capital firms, an understudied phenomenon (Wright, Pruthi, \& Lockett, 2005). We extend prior work in this area emphasizing the domestic supply of venture capital (e.g. Maula \& Makela, 2003), by investigating local demand for venture capital (through national systems of innovation), as well as supporting institutions. We also point to the need to treat the 
choice of international markets as an endogenous one in examining the practices of venture capital firms in those markets.

In particular, we believe that our results on the importance of legal institutions can help improve previous work on cross-national differences in contracting. Our theoretical argument was that in countries with poor protection of investors' rights, venture capitalists will seek more control, but that greater stakes would interfere with the logic of portfolio diversification, thus discouraging investment. Research on the observed contractual arrangements between venture capitalists and entrepreneurs ought to control for the possibility that the former avoid certain countries because the legal system provides weak protections. Our empirical evidence can be readily used to calculate the chances that a common-law firm will fund a venture in a country with a different legal regime, thus helping assess the true effect of legal tradition on organizational growth and investment by taking into account the information provided by the nonoccurrence of investments, i.e. by eliminating the self-selection bias.

Our empirical results also have implications for governments. We found that institutions have a large impact on entry into new markets. The results suggest that the best way for a government to encourage foreign entry in general, and venture capital investment from abroad in particular, is to introduce "horizontal" improvements in the scientific, financial, and political institutional infrastructures, i.e. reforms that benefit all firms and entrepreneurs as opposed to just a chosen few. Hence, governments would be wise to make information about local opportunities and institutional mechanisms as widely available as possible.

The research reported in this paper is limited in several respects. First, we only examined the international expansion of U.S. venture capital firms, ignoring the fact that European firms are more internationally oriented because of the small size of their individual home markets (Maula \& Makela, 2003). Second, the analysis in this paper did not take into account the way in which venture capital firms undertake activities abroad, namely, by establishing a local office or by conducting business directly from the home country. Third, we did not explore if venture capital firms find foreign countries more attractive depending on the types of co-investors available for syndicating or the presence of other home-country venture capital 
firms. These limitations offer opportunities to continue integrating research on venture capital with the international business literature on technological and supporting institutions. Future work can also examine the role of network connections across countries in inducing international investment, or the further impact of institutions on the venture capital practices once they enter a country. 


\section{REFERENCES}

2006. Global Private Equity 2006: Price Waterhouse Coopers.

2007. VentureImpact 2007: The Economic Importance of Venture Capital Backed Companies to the U.S. Economy: Global Insight.

Adams, J. D. \& A. B. Jaffe. 1996. Bounding the effects of R\&D: an investigation using matched establishment-firm data. RAND Journal of Economics, 27(4): 700-21.

Alcacer, J. \& W. Chung. 2007. Location Strategies and Knowledge Spillovers. Management Science, 53(5): 760-76.

Almeida, P. \& B. Kogut. 1999. Localization of knowledge and the mobility of engineers in regional networks. Management Science, 45(7): 905-17.

Audretsch, D. B., E. E. Lehman, \& S. Warning. 2005. University spillovers and new firm location.

Research Policy, 34: 1113-22.

Barry, C. B., J. W. Muscarella, J. W. Peavy III, \& M. R. Vetsuypens. 1990. The Role of Venture Capital in the Creation of Public Companies: Evidence from the Going Public Process. Journal of Financial Economics, 27: 447-71.

Becker, R. \& T. Hellmann. 2005. The Genesis of Venture Capital: Lessons from the German Experience.In C.Keuschnigg \& V.Kanniainen, editors, Venture Capital, Entrepreneurship, and Public Policy. Cambridge: MIT Press.

Black, B. S. \& R. J. Gilson. 1998. Venture capital and the structure of capital markets: Banks versus stock markets. Journal of Financial Economics, 47: 243-77.

Bonacich, P. 1987. Power and Centrality: A Family of Measures. American Journal of Sociology, 92(5): 1170-82.

Bottazzi, L., M. Da Rin, \& T. Hellmann. 2004. The Changing Face of European Venture Capital Industry: Facts and Analysis. Journal of Private Equity, 8(1).

Bottazzi, L., M. Da Rin, \& T. Hellmann. 2005. What Role of Legal Systems in Financial Intermediation? Theory and Evidence.

Cameron, A. C. \& P. K. Trivedi. 1998. Regression Analysis of Count Data. Cambridge, UK: Cambridge University Press.

Chung, W. \& J. Alcacer. 2002. Knowledge Seeking and Location Choice of Foreign Direct Investment in the United States. Management Science, 48(12): 1534-55.

Djankov, S., R. La Porta, F. Lopez-de-Silanes, \& A. Shleifer. 2003. Courts. Quarterly Journal of Economics, 118(2): 453-517.

Fenn, G. W., N. Liang, \& S. Prowse. 1997. The Private Equity Market: An Overview. Financial Markets and Instruments, 6(4): 1-106. 
Florida, R. 1997. The globalization of R \& D: Results of a survey of foreign-affiliated R\&D laboratories in the USA. Research Policy, 26: 85-103.

Florida, R. \& M. Kenney. 1988. Venture Capital and High Technology Entrepreneurship. Journal of Business Venturing, 3(4): 301-19.

Freeman, J. 2005. Venture Capital and Modern Capitalism.In Nee, Victor \& Richard Swedberg, editors, The Economic Sociology of Capitalism. Princeton, NJ: Princeton University Press.

Furman, J. L., M. E. Porter, \& S. Stern. 2002. The determinants of national innovative capacity. Research Policy: 899-933.

Glendon, M. A., M. W. Gordon, \& C. Osakwe. 1994. Comparative Legal Traditions. St. Paul, MN: West.

Gompers, P. \& J. Lerner. 2001. The Money of Invention: How Venture Capital Creates Wealth. Boston, MA: Harvard Business School Press.

Gompers, P. \& J. Lerner. 2000. The Venture Capital Cycle. Cambridge, MA: MIT Press.

Greene, W. H. 1997. Econometric analysis. 3rd ed. Upper Saddle River, NJ: Prentice-Hall.

Guillén, M. F. 2000. Corporate Governance and Globalization: Is There Convergence across Countries? Advances in Comparative International Management, 13: 175-204.

Guillén, M. F. 1994. Models of Management: Work, Authority and Organization from a Comparative Perspective. Chicago: University of Chicago Press.

Guler, I., M. F. Guillén, \& J. M. MacPherson. 2002. Global Competition, Institutions, and the Diffusion of Organizational Practices: The International Spread of the ISO 9000 Quality Certificates. Administrative Science Quarterly, 47: 207-32.

Guthrie, D. 1997. Between markets and politics: Organizational responses to reform in China. American Journal of Sociology, 102(5): 1258-305.

Hall, B. H., A. B. Jaffe, \& M. Trajtenberg. 2001. The NBER Patent Citations Data File: Lessons, Insights and Methodological Tools.

Hall, B. H., N. Link, \& J. T. Scott. 2003. Universities as research partners. Review of Economics and Statistics, 85: 485-91.

Hall, G. \& C. Tu. 2003. Venture Capitalists and the Decision to Invest Overseas. Venture Capital, 5(2): 181-90.

Henisz, W. J. 2000a. The Institutional Environment for Economic Growth. Economics and Politics, 12(1): 1-31.

Henisz, W. J. 2000. The Institutional Environment for Multinational Investment. Journal of Law, Economics and Organization, 16: 334-64.

Henisz, W. J. \& A. Delios. 2001. Uncertainty, Imitation, and Plant Location: Japanese Multinational Corporations, 1990-1996. Administrative Science Quarterly, 46: 443-75. 
Henisz, W. J. \& O. E. Williamson. 1999. Comparative Economic Organization-Within and Between Countries. Business and Politics, 1(3): 261-77.

Hymer, S. 1976. The international operations of national firms: A study of foreign investment. Cambridge, MA: MIT Press.

ICRG. 1996. International Country Risk Guide: Political and Financial Risk Tables. East Syracuse, NY: Political Risk Services Group.

Jaffe, A. B., M. Tratjenberg, \& R. Henderson. 1993. Geographic localization of knowledge spillovers as evidenced by patent citations. Quarterly Journal of Economics, 108(3): 577-98.

Jeng, L. A. \& P. C. Wells. 2000. The determinants of venture capital funding: evidence across countries. Journal of Corporate Finance, 6: 241-89.

Kaplan, S. N., F. Martel, \& P. Stromberg. 2005. How Do Legal Differences and Learning Affect Financial Contracts?

Kenney, M., K. Han, \& S. Tanaka. 2002. Venture Capital Industries in East Asia. Davis, CA: World Bank Report.

Kogut, B. \& S. J. Chang. 1991. Technological Capabilities and Japanese Foreign Direct investment in the United States. Review of Economics \& Statistics, 73(3): 401-13.

Kogut, B. \& U. Zander. 1993. Knowledge of the firm and the evolutionary theory of the multinational corporation. Journal of International Business Studies, 24(4): 625-45.

Kortum, S. \& J. Lerner. 2000. Assessing the contribution of venture capital to innovation. Rand Journal of Economics, 31(4): 2000.

Kuemmerle, W. 1999. The drivers of foreign direct investment into research and development: an empirical investigation. Journal of International Business Studies, 30(1): 1-24.

Kumaresan, N. \& K. Miyazaki. 1999. An Integrated Network Approach to Systems of Innovation-The Case of Robotics in Japan. Research Policy, 28: 563-85.

La Porta, R., F. Lopez-de-Silanes, \& A. Shleifer. 1999. Corporate Ownership around the World. Journal of Finance, 54(2): 471-517.

La Porta, R., F. Lopez-de-Silanes, A. Shleifer, \& R. W. Vishny. 1998. Law and Finance. Journal of Political Economy, 106(6): 113-55.

Leachman, L., V. Kumar, \& S. Orleck. 2002. Explaining Variations in Private Equity: A Panel Approach. Duke Journal of Economics, 14.

Lerner, J. \& A. Schoar. 2005. Does Legal Reinforcement Affect Financial Transactions? The Contractual Channel in Private Equity.

Manigart, S., K. DeWaele, M. Wright, K. Robbie, P. Desbrieres, H. Sapienza, \& A. Beekman. 2000.

Venture Capitalists, Investment Appraisal and Accounting Information: A Comparative Study of the US, UK, France, Belgium, and Holland. European Financial Management, 6(3): 389-403. 
Marshall, M. G. \& K. Jaggers. 2000. Polity IV Project: Political Regime Characteristics and Transitions, 1800-2003.

Maskus, K. E. 2000. Intellectual Property Rights in the Global Economy. Washington, DC: Institute for International Economics.

Maula, M. V. J. \& M. M. Makela. 2003. Cross-border venture capital.In Hyytinen, A. \& M Pajarinen, editors, Financial Systems and Firm Performance: Theoretical and Empirical Perspectives. Helsinki: Taloustieto.

Megginson, W. L. \& K. A. Weiss. 1991. Venture Capitalist Certification in Initial Public Offerings. Journal of Finance, 46(3): 879-903.

Meyer, J. W., J. Boli, G. M. Thomas, \& F. O. Ramirez. 1997. World Society and the Nation-State. American Journal of Sociology, 103(1): 144-81.

Nelson, R. R. \& N. Rosenberg. 1993. Technical Innovation and National Systems.In Nelson, Richard R., editor, National Innovation Systems. New York: Oxford University Press.

Noisi, J. 2002. National systems of innovation are "x-efficient" (and x-effective). Why some are slow learners. Research Policy, 31: 291-302.

North, D. C. 1990. Institutions, Institutional Change and Economic Performance: Cambridge University Press.

North, D. C. \& R. P. Thomas. 1973. The Rise of the Western World: A New Economic History.

Cambridge: Cambridge University Press.

Patel, P. \& K. Pavitt. 1994. National Innovation Systems: Why They are Important, and How They Might Be Measured and Compared. Economics of Innovation \& New Technology, 3: 77-95.

Penrose, E. T. 1959. The theory of the growth of the firm. New York: John Wiley.

Podolny, J. M. 2001. Networks as the Pipes and Prisms of the Market. American Journal of Sociology, 107(1): 33-60.

Podolny, J. M. 2005. Status Signals: A Sociological Study of Market Competition. Princeton, NJ:

Princeton University Press.

Porter, M. E. 1990. The Competitive Advantage of Nations. New York: Free Press.

Powell, W. W., K. W. Koput, J. Bowie, \& L. Smith-Doerr. 2002. The Spatial Clustering of Science and Capital: Accounting for Biotech Firm-Venture Capital Relationships. Regional Studies, 36(3): 291-305.

Reynolds, T. H. \& A. A. Flores. 1989. Foreign Law. Littleton, CO: Rothman.

Romer, P. 1990. Endogenous Technological Change. Journal of Political Economy, 98: S71-S102.

Sahlman, W. A. 1990. The Structure and Governance of Venture Capital Organizations. Journal of Financial Economics, 27: 473-521. 
Schneper, W. D. \& M. F. Guillen. 2004. Stakeholder Rights and Corporate Governance: A CrossNational Study of Hostile Takeovers. Administrative Science Quarterly, 49(2): 263-95.

Scott, W. R. 2001. Institutions and Organizations. 2d ed. Thousand Oaks, CA: Sage.

Shane, S. \& T. Stuart. 2001. Organizational Endowments and Performance of University Start-Ups. Management Science, 48(1): 154-70.

Sorenson, O. \& T. E. Stuart. 2001. Syndication networks and the spatial distribution of venture capital investments. American Journal of Sociology, 106(6): 1546-88.

Spicer, A., G. A. McDermott, \& B. Kogut. 2000. Entrepreneurship and Privatization in Central Europe: The Tenuous Balance Between Destruction and Creation. Academy of Management Journal, 25(3): 63050 .

Stuart, T. E. \& O. Sorenson. 2003a. The geography of opportunity: Spatial heterogeneity in founding rates and the performance of biotechnology firms. Research Policy, 32: 229-53.

Stuart, T. E. \& O. Sorenson. 2003b. Liquidity Events and the Geographic Distribution of Entrepreneurial Activity. Administrative Science Quarterly, 48: 175-201.

Trevino, A. J. 1996. The Sociology of Law: Classical and Contemporary Perspectives. New York: St. Martin's.

Tu, W. 2002. Zero-inflated data.In El-Shaarawi, A. H. \& W. W. Piegorsch, editors, Encyclopedia of Environmetrics. Chichester: John Wiley \& Sons.

Wasserman, N. 2003. The Non-Division of Labor: Knowledge Separability, Structure, and the Upsidedown Venture Capitalist: Harvard Business School.

Weber, M. 1927 [2000]. Commerce on the Stock and Commodity Exchanges. Theory \& Society(29): 33971.

Weber, M. 1978. Economy and Society. Berkeley, CA: University of California Press.

Whitley, R. 1992. Business Systems in East Asia: Firms, Markets, and Societies. London: Sage Publications.

World Bank. 2004. World Development Indicators. Washington, DC: World Bank.

Wright, M., S. Pruthi, \& A. Lockett. 2005. International venture capital research: From cross-country comparisons to crossing borders. International Journal of Management Reviews, 7(3): 135-65.

Zacharakis, A. L., J. S. McMullen, \& D. A. Shepherd. 2007. Venture capitalists' decision policies across three countries: an institutional theory perspective. Journal of International Business Studies, 38: 691708.

Zalan, T. 2004. The Secret Multinationals of the New Millennium: Internationalization of Private Equity Firms, JIBS Literature Review. 
Table1: Descriptive Statistics

Number of rounds VC invested in country

Number of ventures VC invested in country

Patents/GDP

4 Scientific publications/GDP

5 English legal tradition $=1$

6 French legal tradition $=1$

7 German legal tradition $=1$

8 Scandinavian legal tradition $=1$

9 Socialist legal tradition $=1$

10 Stock market capitalization (\% GDP)

11 Policy stability

12 Transnational communities

13 Syndication partners

14 VCF's US experience (\# of ventures)

15 VCF's international experience (\# of foreign ventures)

$16 \operatorname{GDP}\left(* 10^{-12}\right)$

17 Foreign VC experience in country (\# of ventures)

18 VCF's international experience (\# of countries)

19 VCF Centrality

20 Year
Std.

\begin{tabular}{crrrr} 
Obs & \multicolumn{1}{c}{ Mean } & \multicolumn{1}{c}{ Dev. } & \multicolumn{1}{c}{ Min } & \multicolumn{1}{c}{ Max } \\
502208 & 0.00 & 0.15 & 0.00 & 54.00 \\
502208 & 0.00 & 0.09 & 0.00 & 53.00 \\
502208 & 0.81 & 1.40 & 0.00 & 8.76 \\
502208 & 0.03 & 0.03 & 0.00 & 0.19 \\
502208 & 0.34 & 0.48 & 0.00 & 1.00 \\
502208 & 0.37 & 0.48 & 0.00 & 1.00 \\
502208 & 0.06 & 0.23 & 0.00 & 1.00 \\
502208 & 0.06 & 0.24 & 0.00 & 1.00 \\
502208 & 0.17 & 0.37 & 0.00 & 1.00 \\
502208 & 42.17 & 50.38 & 0.01 & 329.96 \\
502208 & 0.56 & 0.28 & 0.00 & 0.89 \\
502208 & 5.25 & 10.30 & 0.05 & 66.84 \\
502208 & 0.05 & 0.45 & 0.00 & 36.00 \\
502208 & 0.54 & 4.02 & 0.00 & 115.00 \\
502208 & 10.85 & 23.70 & 0.00 & 363.00 \\
502208 & 0.28 & 0.74 & 0.00 & 5.71 \\
502208 & 5.00 & 16.12 & 0.00 & 157.00 \\
502208 & 0.79 & 4.55 & 0.00 & 40.00 \\
502208 & 0.02 & 0.03 & 0.00 & 0.23 \\
502208 & 1998.16 & 3.06 & 1991.00 & 2002.00
\end{tabular}


Table 2: Correlations $(\mathrm{N}=502,208)$

1 Number of rounds VC invested in country

2 Number of ventures VC invested in country

3 Patents/GDP

4 Scientific publications/GDP

5 English legal tradition $=1$

6 French legal tradition $=1$

7 German legal tradition $=1$

8 Scandinavian legal tradition $=1$

9 Socialist legal tradition $=1$

10 Stock market capitalization (\% GDP)

11 Policy stability

12 VCF's US experience (\# of ventures)

13 VCF's international experience (\# of foreign ventures)

14 GDP

15 Foreign VC experience in country (\# of ventures)

16 VCF's international experience (\# of countries)

17 VCF Centrality

18 Year

12 VCF's US experience (\# of ventures)

13 VCF's international experience (\# of foreign ventures)

14 GDP

15 Foreign VC experience in country (\# of ventures)

16 VCF's international experience (\# of countries)

17 VCF Centrality

18 Year

$\begin{array}{rrrrrrrrrrr}1 & 2 & 3 & 4 & 5 & 6 & 7 & 8 & 9 & 10 & 11 \\ 1.00 & & & & & & & & & & \\ 0.75 & 1.00 & & & & & & & & & \\ 0.03 & 0.03 & 1.00 & & & & & & & & \\ 0.01 & 0.01 & 0.18 & 1.00 & & & & & & & \\ 0.01 & 0.01 & -0.01 & -0.08 & 1.00 & & & & & & \\ -0.01 & -0.01 & -0.25 & -0.38 & -0.55 & 1.00 & & & & & \\ 0.01 & 0.01 & 0.54 & -0.09 & -0.18 & -0.19 & 1.00 & & & & \\ 0.00 & 0.00 & 0.27 & 0.05 & -0.19 & -0.20 & -0.06 & 1.00 & & & \\ -0.01 & -0.01 & -0.17 & 0.62 & -0.33 & -0.34 & -0.11 & -0.12 & 1.00 & & \\ 0.03 & 0.02 & 0.43 & -0.05 & 0.16 & -0.11 & 0.21 & 0.12 & -0.27 & 1.00 & \\ 0.01 & 0.01 & 0.37 & 0.08 & 0.03 & -0.18 & 0.19 & 0.19 & -0.05 & 0.24 & 1.00 \\ 0.13 & 0.07 & 0.00 & 0.01 & 0.00 & 0.00 & 0.00 & 0.00 & 0.01 & 0.01 & 0.00 \\ 0.05 & 0.03 & 0.01 & 0.03 & 0.00 & -0.01 & -0.01 & 0.00 & 0.02 & 0.02 & 0.00 \\ 0.02 & 0.03 & 0.51 & -0.09 & -0.14 & -0.07 & 0.63 & -0.04 & -0.10 & 0.17 & 0.19 \\ 0.05 & 0.04 & 0.56 & 0.08 & 0.12 & -0.13 & 0.21 & -0.03 & -0.10 & 0.32 & 0.17 \\ 0.06 & 0.04 & 0.01 & 0.01 & 0.00 & -0.01 & 0.00 & 0.00 & 0.01 & 0.01 & 0.00 \\ 0.02 & 0.02 & 0.00 & -0.01 & 0.00 & 0.01 & 0.00 & 0.00 & -0.01 & -0.01 & 0.00 \\ 0.01 & 0.00 & 0.03 & 0.14 & -0.01 & -0.06 & -0.04 & -0.01 & 0.13 & 0.09 & 0.00\end{array}$

$\begin{array}{rrrrrrr}12 & 13 & 14 & 15 & 16 & 17 & 18 \\ 1.00 & & & & & & \\ 0.30 & 1.00 & & & & & \\ 0.00 & 0.00 & 1.00 & & & & \\ 0.02 & 0.04 & 0.50 & 1.00 & & & \\ 0.40 & 0.29 & 0.00 & 0.02 & 1.00 & & \\ 0.15 & 0.72 & 0.00 & -0.02 & 0.18 & 1.00 & \\ 0.07 & 0.18 & -0.02 & 0.21 & 0.09 & -0.11 & 1.00\end{array}$


Table 3: Zero-Inflated Negative Binomial Regression Models Predicting U.S. Venture Capital Firm Investments, 1991- 2002

$\begin{array}{lllll}(1) & (2) & \text { (3) } & \text { (4) } & \text { (5) }\end{array}$

Patents/GDP

Scientific Publications/GDP

French legal tradition

German legal tradition

Scandinavian legal tradition

Socialist legal tradition

Stock market capitalization

Policy stability

VCF's international experience

VCF's US Experience

GDP

Year dummies

Constant

Stage 1

Foreign VC experience in country

VCF's \# of foreign countries

VCF Centrality

Year

Constant

Log pseudo-likelihood Observations Nonzero observations

Robust standard errors in parentheses

${ }^{*} p<0.05,{ }^{* *} p<0.01,{ }^{* * *} p<0.001$
Ventures Rounds Ventures Rounds Ventures Rounds

$0.271^{* * *} \quad 0.316^{*}$

$(0.046) \quad(0.158)$

$13.872^{\star * *} \quad 14.425^{\star * *}$

$0.515^{\star \star *} \quad 0.603^{\star \star \star}$

(0.035) (0.047)

(2.898) (2.964)

$$
\begin{array}{ll}
-0.720^{\star * *} & -0.565^{\star *} \\
(0.168) & (0.196) \\
-2.201^{* * *} & -2.188^{\star * *} \\
(0.402) & (0.449) \\
-1.174^{\star * *} & -1.109^{\star * *} \\
(0.216) & (0.236) \\
-0.732^{\star *} & -0.585^{\star} \\
(0.242) & (0.253)
\end{array}
$$

\begin{tabular}{|c|c|c|c|c|c|}
\hline $\begin{array}{l}0.038^{* * *} \\
(0.006)\end{array}$ & $\begin{array}{l}0.055^{\star * *} \\
(0.011)\end{array}$ & $\begin{array}{l}0.033^{* * *} \\
(0.007)\end{array}$ & $\begin{array}{l}0.049^{* * *} \\
(0.013)\end{array}$ & $\begin{array}{l}0.041^{* * *} \\
(0.005)\end{array}$ & $\begin{array}{l}0.054^{* * *} \\
(0.006)\end{array}$ \\
\hline $0.008^{* *}$ & 0.007 & $0.009^{* * *}$ & $0.011^{\star * *}$ & -0.001 & -0.001 \\
\hline (0.003) & $(0.006)$ & $(0.002)$ & $(0.003)$ & $(0.002)$ & $(0.002)$ \\
\hline-0.011 & -0.068 & $0.181^{* *}$ & $0.146^{*}$ & $0.523^{* * *}$ & $0.642^{* * *}$ \\
\hline (0.051) & (0.078) & (0.073) & (0.065) & $(0.103)$ & $(0.159)$ \\
\hline Included & Included & Included & Included & Included & Included \\
\hline$-3.280^{* * *}$ & $-3.533^{* * *}$ & $-3.437^{\star * *}$ & $-3.594^{* \star *}$ & $-3.307^{\star * *}$ & $-3.825^{\star * *}$ \\
\hline (0.527) & $(0.602)$ & $(0.621)$ & $(0.788)$ & (0.642) & $(0.845)$ \\
\hline$-0.192^{*}$ & -0.139 & $-0.264^{* * *}$ & $-0.263^{* * *}$ & $-0.015^{\star * *}$ & $-0.015^{\star \star \star}$ \\
\hline (0.088) & $(0.169)$ & (0.059) & $(0.067)$ & $(0.003)$ & (0.003) \\
\hline$-0.977^{* *}$ & $-1.445^{*}$ & $-0.780^{* *}$ & $-1.037^{\star \star \star}$ & $-1.383^{\star * *}$ & $-1.838^{* * *}$ \\
\hline (0.349) & $(0.627)$ & $(0.271)$ & $(0.240)$ & $(0.188)$ & $(0.181)$ \\
\hline$-7.748^{* *}$ & -9.14 & $-6.652^{* *}$ & $-6.515^{\star *}$ & $-16.797^{\star \star \star}$ & $-16.987^{* * *}$ \\
\hline (2.812) & (5.058) & (2.540) & (2.221) & (2.461) & (2.169) \\
\hline-0.029 & 0.057 & 0.052 & $0.143^{*}$ & $-0.165^{\star \star *}$ & -0.075 \\
\hline (0.082) & (0.104) & $(0.064)$ & $(0.064)$ & $(0.051)$ & $(0.064)$ \\
\hline 62.919 & -110.482 & -99.109 & $-280.332^{*}$ & $334.778^{\star * *}$ & '154.531 \\
\hline 163.445 & (208.068) & (127.824) & (127.474) & (101.908) & $(127.701)$ \\
\hline-4183.987 & -5582.248 & -4230.125 & -5635.955 & -4058.432 & -5401.751 \\
\hline 502208 & 502208 & 502208 & 502208 & 502208 & 502208 \\
\hline 687 & 896 & 687 & 896 & 687 & 896 \\
\hline
\end{tabular}


Table 3 (continued): Zero-Inflated Negative Binomial Regression Models Predicting U.S. Venture Capital Firm Investments, 1991- 2002

\begin{tabular}{|c|c|c|c|c|c|c|}
\hline \multirow{4}{*}{ Patents/GDP } & (7) & (8) & (9) & $(10)$ & $(11)$ & (12) \\
\hline & Ventures & Rounds & Ventures & Rounds & Ventures & Rounds \\
\hline & & & $0.487^{\star \star \star}$ & $0.506^{* * *}$ & & \\
\hline & & & $(0.041)$ & $(0.043)$ & & \\
\hline \multirow[t]{2}{*}{ Scientific Publications/GDP } & $12.384^{\star \star \star}$ & $12.207^{\star \star \star}$ & & & 12.693 & $20.824^{\star \star \star}$ \\
\hline & (3.611) & (3.581) & & & $(7.208)$ & $(5.411)$ \\
\hline \multirow[t]{2}{*}{ French legal tradition } & $-0.623^{* * *}$ & $-0.471^{*}$ & $-0.423^{*}$ & -0.269 & -0.382 & $-0.504^{*}$ \\
\hline & $(0.193)$ & $(0.235)$ & $(0.186)$ & $(0.205)$ & $(0.203)$ & $(0.218)$ \\
\hline \multirow[t]{2}{*}{ German legal tradition } & -0.294 & -0.257 & $-2.089^{\star \star \star}$ & $-2.068^{\star * *}$ & -0.284 & $-1.244^{\star * \star}$ \\
\hline & $(0.318)$ & $(0.375)$ & $(0.298)$ & $(0.330)$ & (0.315) & $(0.368)$ \\
\hline \multirow[t]{2}{*}{ Scandinavian legal tradition } & -0.056 & 0.087 & $-1.455^{\star \star \star}$ & $-1.226^{\star \star *}$ & -0.308 & $-0.702^{\star *}$ \\
\hline & $(0.280)$ & $(0.293)$ & $(0.244)$ & $(0.262)$ & $(0.392)$ & $(0.243)$ \\
\hline \multirow[t]{2}{*}{ Socialist legal tradition } & $-1.339^{* * *}$ & $-1.291^{* * *}$ & 0.020 & 0.255 & -0.699 & $-1.077^{*}$ \\
\hline & $(0.309)$ & $(0.333)$ & $(0.228)$ & $(0.241)$ & $(0.578)$ & $(0.542)$ \\
\hline \multirow[t]{2}{*}{ Stock market capitalization } & & & $0.009^{* * *}$ & $0.010^{* * *}$ & $0.006^{* * *}$ & $0.011^{* * *}$ \\
\hline & & & $(0.001)$ & $(0.001)$ & $(0.001)$ & $(0.001)$ \\
\hline \multirow[t]{2}{*}{ Policy stability } & & & $0.891^{*}$ & $0.996^{* *}$ & $1.556^{\star * *}$ & $1.575^{* * *}$ \\
\hline & & & $(0.409)$ & $(0.334)$ & $(0.459)$ & $(0.478)$ \\
\hline \multirow[t]{2}{*}{ VCF's international experience } & $0.036^{* * *}$ & $0.052^{* * *}$ & $0.043^{\star * *}$ & $0.056^{\star * *}$ & $0.039^{\star \star *}$ & $0.050^{* * *}$ \\
\hline & $(0.007)$ & $(0.013)$ & $(0.005)$ & $(0.006)$ & $(0.006)$ & $(0.007)$ \\
\hline \multirow[t]{2}{*}{ VCF's US Experience } & $0.009^{* * *}$ & $0.010^{\star *}$ & -0.001 & -0.000 & $0.007^{*}$ & 0.001 \\
\hline & $(0.003)$ & $(0.003)$ & $(0.002)$ & $(0.002)$ & $(0.003)$ & $(0.001)$ \\
\hline \multirow[t]{2}{*}{ GDP } & $0.192^{*}$ & 0.153 & $0.509^{* * *}$ & $0.589^{* * *}$ & 0.179 & $0.732^{* * *}$ \\
\hline & $(0.090)$ & $(0.090)$ & $(0.084)$ & $(0.105)$ & $(0.107)$ & $(0.115)$ \\
\hline Year dummies & Included & Included & Included & Included & Included & Included \\
\hline \multirow[t]{2}{*}{ Constant } & $-3.109^{\star * *}$ & $-3.325^{\star * *}$ & $-4.090^{\star * *}$ & $-4.527^{\star \star \star}$ & $-4.215^{\star \star *}$ & $-4.714^{\star * *}$ \\
\hline & $(0.691)$ & $(0.850)$ & $(0.742)$ & $(0.847)$ & $(0.711)$ & $(1.089)$ \\
\hline \multicolumn{7}{|l|}{ Stage1 } \\
\hline \multirow[t]{2}{*}{ Foreign VC experience in country } & $-0.223^{* *}$ & $-0.223^{*}$ & $-0.011^{\star \star \star}$ & $-0.013^{\star \star *}$ & -0.133 & $-0.021^{* \star *}$ \\
\hline & $(0.080)$ & $(0.095)$ & $(0.003)$ & $(0.003)$ & $(0.097)$ & $(0.003)$ \\
\hline \multirow[t]{2}{*}{ VCF's \# of foreign countries } & $-0.871^{\star *}$ & $-1.139^{* * *}$ & $-1.425^{\star * *}$ & $-1.887^{* * *}$ & $-1.094^{* *}$ & $-1.791^{* * *}$ \\
\hline & $(0.301)$ & $(0.288)$ & $(0.184)$ & $(0.181)$ & $(0.393)$ & $(0.188)$ \\
\hline \multirow[t]{2}{*}{ VCF Centrality } & $-6.991^{* *}$ & $-7.001^{* *}$ & $-17.005^{\star * \star}$ & $-16.713^{\star * *}$ & $-9.155^{\star}$ & $-15.035^{\star * *}$ \\
\hline & $(2.650)$ & $(2.675)$ & $(2.52)$ & $(2.145)$ & (3.647) & (2.094) \\
\hline \multirow[t]{2}{*}{ Year } & 0.002 & 0.106 & $-0.212^{\star * *}$ & $-0.121^{*}$ & -0.071 & -0.076 \\
\hline & $(0.085)$ & $(0.081)$ & $(0.047)$ & $(0.058)$ & $(0.105)$ & $(0.052)$ \\
\hline \multirow[t]{2}{*}{ Constant } & -0.113 & -207.497 & $427.587^{* * *}$ & -245.921 & 145.525 & 157.149 \\
\hline & $(170.569)$ & $(161.526)$ & $(95.133)$ & $(115.304)$ & $(209.485)$ & $(103.286)$ \\
\hline Log pseudo-likelihood & -4195.318 & -5601.763 & -3979.971 & -5283.900 & -4143.295 & -5427.065 \\
\hline Observations & 502208 & 502208 & 502208 & 502208 & 502208 & 502208 \\
\hline Nonzero observations & 687 & 896 & 687 & 896 & 687 & 896 \\
\hline
\end{tabular}

Robust standard errors in parentheses

${ }^{*} p<0.05,{ }^{* *} p<0.01,{ }^{* * *} p<0.001$ 
Table 4: Magnitude of the Statistically Significant Hypothesized Effects on the Numbers of Ventures or Rounds (in percentages)

$\begin{array}{lcccc}\text { Change in: } & \text { Ventures } & \text { Rounds } & \text { Ventures } & \text { Rounds } \\ \text { Patents/GDP } & 97.7 & 103.1 & \ldots & \ldots \\ \text { Scientific publications/GDP } & \ldots & \ldots & 46.3 & 86.7 \\ \text { Stock market capitalization } & 57.4 & 65.5 & 35.3 & 74.1 \\ \text { Policy stability } & 28.3 & 32.2 & 54.6 & 55.4\end{array}$

Note: Based on the regression estimates reported in Table 3, models 9-12. The formula for calculating the percent change in the number of investments in response to a one standard deviation change in the independent variable is: $\{[\exp (\beta \times s d)-1]\} \times 100$, where $\beta$ is the parameter estimate and sd is the standard deviation. 
Appendix. List of countries in the sample

\begin{tabular}{|c|c|c|}
\hline Argentina & Honduras & Oman \\
\hline Armenia & Hungary & Panama \\
\hline Australia & Iceland & Paraguay \\
\hline Austria & India & Peru \\
\hline Azerbaijan & Indonesia & Philippines \\
\hline Bahrain & Ireland & Poland \\
\hline Bangladesh & Israel & Portugal \\
\hline Belgium & Italy & Russian Federation \\
\hline Bolivia & Jamaica & Singapore \\
\hline Botswana & Japan & Slovak Republic \\
\hline Brazil & Jordan & Slovenia \\
\hline Bulgaria & Kenya & South Africa \\
\hline Canada & $\begin{array}{l}\text { Korea, Republic } \\
\text { of }\end{array}$ & Spain \\
\hline Chile & Kuwait & Sri Lanka \\
\hline China & Kyrgyz Republic & Swaziland \\
\hline Colombia & Latvia & Sweden \\
\hline Costa Rica & Lebanon & Switzerland \\
\hline Ivory Coast & Lithuania & Tanzania \\
\hline Croatia & Luxembourg & Thailand \\
\hline Cyprus & Macedonia, FYR & Trinidad and Tobago \\
\hline Czech Republic & Malawi & Uganda \\
\hline Denmark & Malaysia & Ukraine \\
\hline $\begin{array}{l}\text { Dominican } \\
\text { Republic }\end{array}$ & Mauritius & $\begin{array}{l}\text { United Arab } \\
\text { Emirates }\end{array}$ \\
\hline Ecuador & Mexico & United Kingdom \\
\hline Egypt & Moldova & United States \\
\hline El Salvador & Mongolia & Uruguay \\
\hline Estonia & Morocco & Venezuela \\
\hline Fiji & Namibia & Zambia \\
\hline Finland & Nepal & Zimbabwe \\
\hline France & Netherlands & \\
\hline Germany & New Zealand & \\
\hline Greece & Nigeria & \\
\hline Guatemala & Norway & \\
\hline
\end{tabular}




\section{End Notes}

1 “The Global Startup," Forbes Global, 29 November 2004.

${ }^{2}$ Erel Margalit, founder of Jerusalem Venture Partners. See “The Global Startup,” Forbes Global, 29 November 2004.

${ }^{3}$ Interviews with K. O. Chia, formerly a principal at a Hong Kong VC firm, and Chen Siwei, National People's Congress and Chinese Academy of Sciences.

${ }^{4}$ In the discussion pertinent to the venture capital industry we use the term "firm" solely to refer to venture capital firms and "company" or "venture" to refer to portfolio companies (entrepreneurial ventures).

${ }^{5}$ Other studies have focused on differences in decision making (Manigart, DeWaele, Wright, Robbie, Desbrieres, Sapienza, \& Beekman, 2000) or on the willingness to invest abroad (Hall \& Tu, 2003). ${ }^{6}$ Becker and Hellman (2005) argue that, while having an active capital market is important to venture capital, it is not sufficient. In the 1970s and 80s, government-supported experiments with establishing a domestic venture capital industry failed in Germany, in spite of the existence of well-developed capital markets (Becker \& Hellmann, 2005).

${ }^{7}$ VentureXpert includes "standard U.S. venture investing" in portfolio companies, as long as the company is domiciled in the U.S., at least one of the investors is a venture capital firm, venture investment is a primary investment, and it entails an equity transaction.

${ }^{8}$ While the number of venture capital firms represented in the sample may seem high, it should be noted that not all firms are active during the entire period of observation. We checked the sensitivity of our results by excluding VC firms that made fewer than three investments in the US in each year. This resulted in a sample of 552 firms and 242,017 firm-country-years. The results of the analyses with the reduced sample are qualitatively similar to the ones reported here.

${ }^{9}$ Our analyses of this loss of information did not reveal any significant biases in the sense that the years for which information was not available for some of the countries appeared to be random. The countries 
with more missing years of data on some variables tended to be less developed than the countries with more complete data. In the empirical analysis we control for the level of economic development, which did not alter the general pattern of results. We considered using multiple imputation techniques, but the fact that we are not using ordinary least-squares estimation but a zero-inflated negative binomial model prevented us from implementing them in an appropriate way. 